\title{
Anaerobic Biogas Generation for Rural Area Energy Provision in Africa
}

\author{
B. Amigun ${ }^{1,}$, , W. Parawira ${ }^{2}$, J. K. Musango ${ }^{3}$, \\ A. O. Aboyade ${ }^{4}$ and A. S. Badmos ${ }^{1}$ \\ ${ }^{1}$ Renewable Energy Group, National Biotechnology Development Agency (NABDA)- \\ an Agency Under the Federal Ministry of Science and Technology, Abuja, \\ ${ }^{2}$ Department of Applied Biology, \\ Kigali Institute of Science and Technology (KIST), Kigali, \\ ${ }^{3}$ Gauteng City-Region Observatory, a Partnership Between University of Johannesburg, \\ University of Witwatersrand and Gauteng Provincial Government, Wits, \\ ${ }_{4}^{4}$ rocess Engineering Department, Stellenbosch University, Stellenbosch, \\ ${ }^{1}$ Nigeria \\ ${ }^{2}$ Rwanda \\ 3,4South Africa
}

\section{Introduction}

\subsection{Energy overview in Africa}

Energy plays a central role in national development process as a domestic necessity and major factor of production, whose cost directly affects price of other goods and services (Amigun and von Blottnitz, 2008). It affects all aspects of development, such as social, economic, political and environmental, including access to health, water, agricultural productivity, industrial productivity, education and other vital services that improve the quality of life. Currently, many African countries experience frequent blackouts and the cost of electricity blackouts is not known. The continent's energy consumption and demand is expected to continue to grow as development progresses at rates faster than those of developed countries. The desire for improved quality of life and rises in population together with energy demands from the transport, industrial and domestic sectors will continue to drive this growth. Ensuring the provision of adequate, affordable, efficient and reliable high-quality energy services with minimum adverse effect on the environment in sustainable way is not only pivotal for development, but crucial for African countries most of which are struggling to meet present energy demands (Amigun et al., 2008). African countries need sustainable energy supplies to be in a position to improve their overall net productivity and become major players in global technological and economic progress. Unreliable energy supply may account for the low levels of private investment the African continent attracts and the poor economic productivity of its limited industries. Improvement

${ }^{*}$ Corresponding Author 
in the quality and magnitude of energy services in developing countries is required for them to meet developmental objectives including the Millennium Development Goals (MDGs). Africa is not only the poorest continent in the world but it was the only major developing region with negative growth in income per capita during 1980-2000 (World Bank, 2003).

Although reliable regional energy statistics are not readily available, existing estimates of energy use in Eastern and Southern Africa indicate a significant and persistent dependence on traditional biomass energy technologies and limited use of modern, sustainable energy technologies (Karekezi, 1994a). Biomass in the form of mainly wood-fuel and charcoal is the dominant energy source used in sub-Saharan Africa

Because of the shortage in commercial modern energy and current economic situation in most African countries, the fuel substitution away from biomass is less likely because of declining disposable incomes for both urban and rural population. There is fuel-switch back to traditional fuels as modern fuels become scarce in some areas but the wood fuels are also becoming scarce in some countries. Biomass is cheap but when used in an unplanned (unsustainable) manner leads to consumption beyond regenerative limits with serious environmental consequences. On average, about $40 \%$ of total commercial energy is consumed in six countries in the Northern sub-region and a similar share in Southern Africa with over $80 \%$ by South Africa. The other 45 or more countries share the remaining $20 \%$. Similarly, the major oil and gas producers are limited to about ten countries in the North and West regions while about 95\% coal (anthracite in nature) is produced in South Africa. This uneven distribution of the fossil energy resources (crude oil and natural gas) on the African continent is reflected in the energy production and consumption patterns (Table 1). As a result, $70 \%$ of countries on the continent depend on imported energy resources, which support the need to harness the available abundant renewable energy resources (Amigun, 2008).

\begin{tabular}{lll}
\hline Major energy exporter & Net energy exporter & Importers \\
\hline Nigeria & Angola & Benin \\
Algeria & Cameroon & Eritrea \\
Libya & Congo & Ethiopia \\
South Africa & Democratic Republic of & Ghana \\
& Congo & \\
Egypt & Cote d' Ivoire & Kenya \\
Gabon & Gabon & Morocco \\
Congo & Sudan & Mozambique \\
& & Namibia \\
& & Senegal \\
& & Tanzania \\
& & Togo \\
& & Zambia \\
& & Zimbabwe \\
\hline
\end{tabular}

${ }^{a}$ Major energy exports are in excess of 0.5 quads

${ }^{b}$ Most of the African countries energy imports are very small (less than 0.3 quads)

Table 1. The energy distribution in Africa indicating countries which export and import energy (Amigun et al., 2008) 
Africa is a net energy exporter, but the majority of its population lacks access to modern fuels, and many countries rely on imported energy. More than 500 million people living in sub-Saharan Africa do not have electricity in their homes and rely on solid forms of biomass (firewood, agricultural residues, animal wastes, etc) to meet basic energy needs for cooking, heating and lighting. The disadvantages of these traditional fuels are many: they are inefficient energy carriers and their heat is difficult to control, they produce dangerous emissions and their current rate of extraction is not sustainable. The unsustainable use of fuel wood biomass can accelerate deforestation and lead to soil erosion, desertification and increased risk of flooding and biodiversity loss. The low levels of modern (commercial) energy consumption prevalent in Africa besides the heavy usage of traditional (noncommercial) biofuels- primarily biomass is also due to largely underdeveloped energy resources, poorly developed commercial energy infrastructure, widespread and severe poverty which makes it impossible for people to pay for conventional energy resources and the landlocked status of some African countries that make the cost of importing commercial energy more expensive (World Bank, 2003; Amigun et al., 2008). The existing aging and neglected facilities for thermal and hydro energy production need rehabilitation and expansion for the efficient delivery of useful energy services. Upgrading the abundant biomass in Africa to higher-quality energy carriers could help change the energy situation in the continent. The problems arising from non-sustainable use of fossil fuels and traditional biomass fuels have led to increased awareness and widespread research on the accessibility of new and renewable energy resources, such as biogas. The development of renewable energy technologies and in particular biogas technology can help reduce the dependence on non-renewable resources and minimise the social impacts and environmental degradation problems associated with fossil fuel (Amigun and von Blottnitz, 2008).

\subsection{The role of renewable energy: Biogas technology (anaerobic digestion)}

As mentioned above, the economic prosperity and quality of life of a country are closely linked to the level of its per capita energy consumption and the strategy adopted to use energy as a fundamental tool to achieve the same (Amigun et al. 2008; Singh \& Sooch 2004). This is illustrated in Figure 1.

Renewable energy could provide the much desired sustainable rural revitalization in most developing countries. It is an ideal alternative because it could be a less expensive option for low income communities. An ideal renewable energy source is one which is locally available, affordable and can be easily used and managed by local communities. Anaerobic digestion is one of a number of technologies that offers the technical possibility of decentralized approaches to the provision of modern energy services using resources such as; cow dung, human waste and agricultural residues to produce energy. Anaerobic digestion of the large quantities of municipal, industrial and agricultural solid waste in Africa can provide biogas that can be used for heat and electricity production and the digester residue can be recycled to agriculture as a secondary fertilizer. Anaerobic digestion systems are relatively simple, economical, and can operate from small to large scales in urban and rural locations (Amigun \& von Blottnitz, 2009). In this regard, many African governments have realised that renewable energies could play a very important role in supplementing other existing energy sources. 


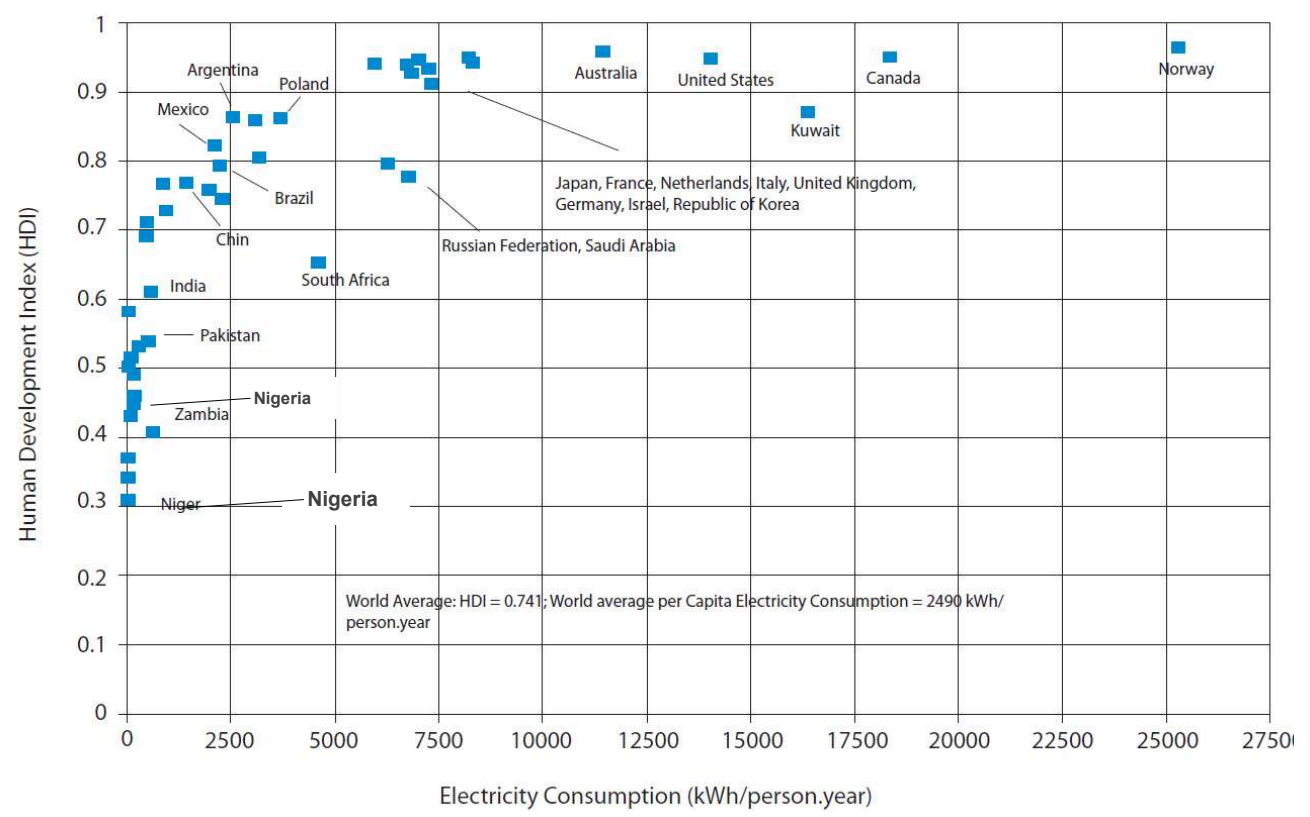

Fig. 1. Human development index (HDI) and per capita electricity consumption, 2003 2004, (Source: UNDP, 2006)

Anaerobic digestion describes the natural breakdown of organic matter in the absence of oxygen into a methane rich gas (biogas) via the complex and synergistic interactions of various micro-organisms types including hydrolytic, fermentative, acidogenic, and methanogenic bacteria (Lusk et al. 1996, Parawira, 2004b). The first group of microorganism secretes enzymes, which hydrolyses polymeric materials such as proteins and polysaccharides to monomers such as glucose and amino acids. The fermentative bacteria convert these monomers to organic acids, primarily propionic and acetic acid. The acidogenic bacteria convert these acids to hydrogen, carbon dioxide, and acetate, which the methanogens utilize via two major pathways to produce methane and carbon dioxide (Lusk et al. 1996; Verma 2002). The potential for organic matter decomposition to generate a flammable gas has been recognized for more than 400 years. In 1808, it was determined that methane was present in the gases produced during the anaerobic digestion of cattle manure. In 1868, Bechamp, a student of Pasteur attempted to isolate the microorganism responsible for the anaerobic bioconversion of ethanol to methane.

The first practical application of anaerobic digestion for energy production took place in England in 1896 when biogas from sewage sludge digestion was used to fuel street lamps. As is the case for many other renewable technologies, interests in anaerobic digestion suffered with the rise of the dependence of petroleum. However some developing countries, mainly in Asia, embraced the technology for the small scale provision of energy and sanitation services (Monnet 2003). Since that time, anaerobic digestion has received considerable interest to harness its waste disposal and energy producing capabilities, with municipal sewage disposal attracting the widest application (Lusk et al. 1996). 
The anaerobic digestion process will occur at most temperatures below $70^{\circ} \mathrm{C}$, but in the commercial operation of digesters two main temperature ranges are typically employed; the mesophilic range $\left(30-44^{\circ} \mathrm{C}\right)$ and thermophilic range $\left(45-60^{\circ} \mathrm{C}\right)$. In addition to sewage sludge, organic farm wastes, municipal solid waste, green botanical waste and organic industrial waste have also been used as feedstock in various small to large scale digesters across the world. Current commercial anaerobic digestion processes generally involve the following steps; pre-treatment (including size reduction and the separation of non-biodegradable substances), digestion, biogas cleaning and conditioning (to remove $\mathrm{CO}_{2}$, water vapour and other undesirables), and subsequently biogas utilization (via internal combustion engines, or the more efficient combined heat and power plant (CHP)). The solid residue from the digestion process (called digestate) can be used as compost.

Various types of small to medium scale biogas digesters have been developed including the floating drum, fixed dome, and plastic bag design (Amigun \& Blottnitz 2007). The amount of biogas produced from a specific digester depends on factors such as the amount of material fed, the type of material, the carbon/nitrogen ratio, and digestion time and temperature (Omer \& Fadalla 2003; Schwart et al. 2005; Chynoweth et al. 2001). Depending on the context, any type may be used. However, most of the small to medium scale biogas plants built so far are of the fixed dome type (Amigun \& von Blottnitz 2009). The technology is gradually gaining popularity in developing countries, especially in Africa where the lack of clean and sustainable energy source represents damage to the environment and its people (Amigun \& von Blottnitz 2009). In addition, Sub-Saharan Africa with its warm climates is well-suited for the biogas digester technology (Aboyade 2004).

In the subsequent sections of this chapter, the current state of status of biogas technology in sub-Saharan Africa will be presented, along with a discussion of opportunities and challenges faced. The socio-economic benefits of biogas digesters is also been investigated through the use of case studies of commercial and demonstration plants on the continent. The economics of biogas technology in terms of investment and maintenance in the rural African context is discussed.

\section{Biogas technology overview and status in Africa}

Biogas technology is viewed as one of the renewable technologies in Africa that can help eases its energy and environmental problems. To date, some digesters have been installed in several sub-Saharan countries, utilising a variety of waste such as from slaughterhouses, municipal wastes, industrial waste, animal dung and human excreta. Small-scale biogas plants are located all over the continent but very few of them are operational. In most African countries, for example, Burundi, Ivory Coast, and Tanzania, biogas is produced through anaerobic digestion of human and animal excreta using the Chinese fixed-dome digester and the Indian floating-cover biogas digester, which are not reliable and have poor performance in most cases (Omer and Fadalla, 2003). These plants were built for schools, health clinics and mission hospitals and small-scale farmers, in most cases by nongovernmental organisations. In Africa the interest in biogas technology has been further stimulated by the promotional efforts of various international organisations and foreign aid agencies through their publications, meetings and visits. Most of the plants have only operated for a short period due to poor technical quality. Table 3 gives a list of the African countries with biogas production units as at 2007. There is thus a need to introduce more 
efficient reactors to improve both the biogas yields and the reputation of the technology. The development of large-scale anaerobic digestion technology in Africa is still embryonic, but with a lot of potentials.

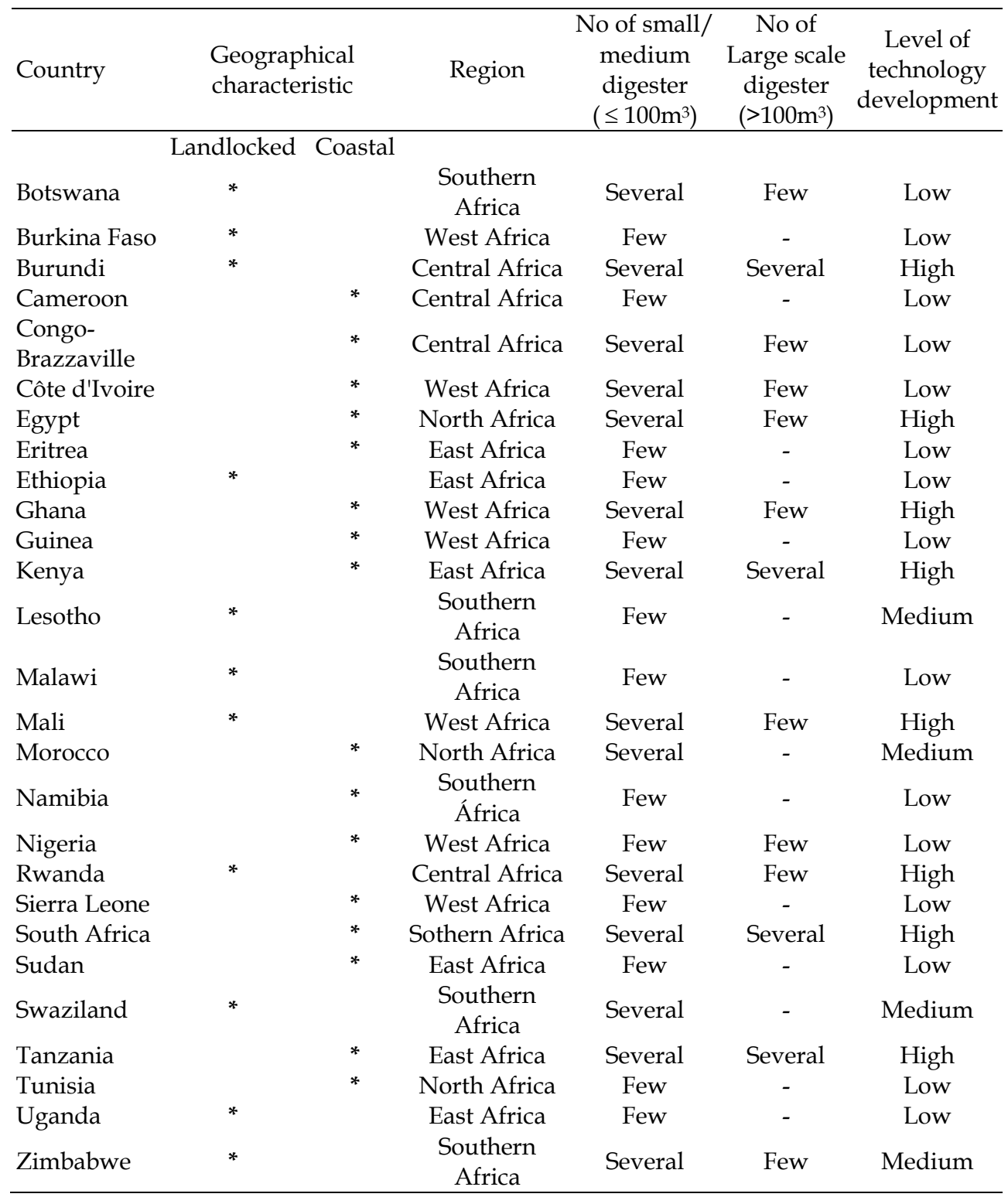

Sources: Karekezi, (2002), Allafrica.com, (2000), Akinbami et al, (2001), Spore, (2004), Amigun and von Blottnitz, (2007).

Table 2. Countries with documented biogas producing units in Africa as at 2007 
Some of the first biogas digesters were set up in Africa in the 1950s in South Africa and Kenya. In other countries such as in Tanzania, biogas digesters were first introduced in 1975 and in others even more recently (South Sudan in 2001). To date, biogas digesters have been installed in several sub-Saharan countries including Burundi, Botswana, Burkina Faso, Cote d'Ivoire, Ethiopia, Ghana, Guinea, Lesotho, Namibia, Nigeria, Rwanda, Zimbabwe, South Africa and Uganda (Winrock International, 2007). Biogas digesters have utilized a variety of inputs such as waste from slaughterhouses, waste in urban landfill sites, industrial waste (such as bagasse from sugar factories), water hyacinth plants, animal dung and human excreta. Biogas digesters have been installed in various places including commercial farms (such as in chicken and dairy farms in Burundi), a public latrine block (in Kibera, Kenya), prisons in Rwanda, and health clinics and mission hospitals (in Tanzania) (Winrock International, 2007). However, by far the most widely attempted model is the household biogas digester - largely using domestic animal excreta (Table 2). This is due to the fact that this technology is closely linked to poverty alleviation and rural development. The biogas produced from these household-level systems has been used mostly for cooking, with some use for lighting.

Global experience shows that biogas technology is a simple and readily usable technology that does not require overtly sophisticated capacity to construct and manage. It has also been recognized as a simple, adaptable and locally acceptable technology for Africa (Gunnerson and Stuckey, 1986; Taleghani and Kia, 2005). There are some cases of successful biogas intervention in Africa, which demonstrate the effectiveness of the technology and its relevance for the region. The lessons learned from biogas experiences in Africa suggest that having a realistic and modest initial introductory phase for Biogas intervention; taking into account the convenience factors in terms of plant operation and functionality; identifying the optimum plant size and subsidy level; and; having provision for design adaptation are key factors for successful biogas implementation in Africa (Biogas for better life, 2007). Biogas technology has multiple beneficial effects.

\subsection{Challenges to biogas commercialisation in Africa and possible measures to overcome them}

The implementation of the biogas technology on large scale may be prevented or slowed down by a number of constraints. They may be grouped as follows: political, social-cultural, financial, informational, institutional, technical and training (Omer and Fadalla, 2003, Ni and Nyns, 1996). Some of the difficulties encountered in the development of anaerobic treatment for biogas production in developing countries are in Table 3.

There is lack of coherent biogas technology strategy in many sub-Saharan African countries despite the increase in the price of conventional fuel on a daily basis, and their rising demand mainly to technical and non-technical factors. The main contentious problems of biogas commercialisation in sub-Saharan African countries relate to economics and political will and many site-specific issues. Some of these issues are informed by local dynamics of perceptions; influenced by personal, social and institutional factors and beliefs, as well as internal conflicts, due to perceived environmental, social and ecological risks, that were aggravated by miscommunication and the lack of understanding. 
- Inexperienced contractors and consultants, resulting in poor-quality plants, and poor choice of materials.

- Lack of reliable information on the potential benefits of the technology by financial institutions.

- Complete absence of academic, bureaucratic, legislation and commercial infrastructure in the region/country.

- Lack of knowledge on the system in practice, sometimes even in research institutes and universities.

- Community acceptance issues and poor ownership responsibility by users.

- Complete absence of pilot studies, and no full-scale experience.

- No properly educated operators, lack of credibility, lack of technical knowledge on maintenance and repair.

- Uninformed or poorly informed authorities and policy makers.

- Failure by government to support biogas technology through focussed energy policy.

- Research at universities is frequently considered to be too academic in nature, even when it is quite applied.

Table 3. Some of the difficulties thwarting development of biogas technology in Africa (Mwakaje, 2007; Murphy, 2001, Lettinga, 2001; Lettinga, 1995, Switzenbum, 1995; Tafdrup, 1995; Iza et al., 1991)

\subsubsection{Economic factors which affect biogas production and commercialisation}

The economy of a biogas plant consists of large investments costs, some operation and maintenance costs, mostly free raw materials, e.g., animal dung, water, aquatic weeds, terrestrial plants, sewage sludge, industrial wastes, agricultural wastes and income from sale of biogas or electricity and heat (Amigun and von Blottnitz, 2007). The economics of biogas production and consumption is dependent on a number of factors specific to the local situation, as shown in Table 4. The economics of biogas production and use, therefore, depends upon the specific country and project situation

a. Cost of biomass material, which varies among countries depending on land availability, agricultural productivity, labour costs, etc

b. Biogas production costs, which depends on the plant location, size and technology, which vary among countries

c. The cost of corresponding fossil fuel (gasoline, diesel) in individual countries

d. The strategic benefit of substituting imported petroleum with domestic resources

Table 4. Economic factors which affect biogas production and commercialisation

The main limitations to the adoption of large-scale biogas technology are both institutional and economic. Establishing a self-sustaining institutional system that can collect and process urban waste and effectively market the generated biogas fuel is a complex activity that calls for sophisticated organisational capability and initiative (Karekezi, 1994b). The energy transition in Africa is an incremental process and not a leapfrog process, dependent upon household, national and regional accumulations of technological capabilities. Biogas technology absorption, therefore, cannot occur without the proper social, cultural, political and economic institutions to support adoption, dissemination and appropriate contextual 
innovation (Murphy, 2001). The Taka Gas Project in Tanzania (Mbuligwe and Kassenga, 2004) is a very good example of how large-scale biogas technology projects have failed to take off in Africa. The main objective of the Taka Gas Project was to obtain biogas through anaerobic digestion of municipal solid waste from Dar es Salaam city and serve as a model for other urban areas in Africa to emulate. The project was well prepared with analysis of solid waste as feedstock for the project, strategies for operationalising the project, environmental impacts and economic feasibility and other technical and non-technical and socio-economic issues studied for the project but it has never took off the ground due to bureaucracy.

The investment cost of even the smallest of the biogas units is prohibitive for most rural households of sub-Saharan Africa. Evidence from the experiences in Eastern and Southern African countries is still limited, but the general consensus is that the larger combined septic tank/biogas units that are run by institutions such as hospitals and schools have proved to be more viable than the small-scale household bio-digesters. There is need for subsidy-led programmes which will be demand-driven and market-oriented to increase the adoption of biogas plants. Subsidies are justified to make up for the difference between ability to pay and the higher societal benefits (maintenance of forest cover, prevention of land degradation, and reduction in emissions of greenhouse gases) and private benefits (reduction in expenditure for firewood and kerosene, savings in time for cooking and firewood collection and health) accruing to users. Besides the expense, many consumers are hesitant to adopt the biogas technology reflecting the lack of public awareness of the relevant issues. To date, this combination of factors has largely stifled the use of biogas technology in Africa.

\subsubsection{Political factors affecting biogas production and commercialisation}

The political barriers that exist are mainly in the area of sovereignty rights and the will to initiate national biogas technology programmes. Another problem is the high number of armed conflicts and political instability in the continent which together with the region's debt burden have reduced the region's credibility. Hence, providing capital even for modest investments will prove difficult. African governments need to commit themselves to renewable energy programmes. Government constant commitments to the development and promotion of renewable energy sources have been instrumental in promoting an ambitious alcohol fuel in Brazil, biogas programmes in Europe, China and India. It could be helpful to learn from the experiences gained in the developed world but adapted to the needs and situation in developing countries. However, in some African countries, the hostile social climate and political instability prevent opportunities of international collaboration and support.

\subsubsection{Technical factors affecting biogas production and commercialisation}

There are three major types of digesters that have been in use in developing countries: Chinese fixed dome digester, the Indian floating drum digester and the more recent tube digesters. These reactors are small in size $\left(5-10 \mathrm{~m}^{3}\right)$ and mostly used at household level to deliver the energy demand for household cooking and lighting. The advantages of these reactors are that they are inexpensive compared to sophisticated systems, can be built with 
locally available material, are easy to handle and do not have moving parts which are prone to failure. The working principle of these reactors is the same although there are substantial differences between them. The substrate enters through the inlet pipe into the digester tank where the substrate has an average retention time of 10-30 days. The biogas is collected above the slurry and leaves the tank through a gas pipe into the top cover. In the fixed dome digester, the top is made of concrete or bricks as the rest of the digester below ground. The floating cover type has steel cover floating on the slurry, which is above ground, whereas the rest of the digester is also below the ground. The digested slurry leaves the digester through an outlet pipe and is collected in outlet pit. However, these digesters have several limitations. Each of the digester type does not have facilities for mixing the slurry or for maintaining a certain temperature in the digester and controlling it. There are also no facilities to remove sand, stones and other non-digestible materials, which will over the years, accumulate and decrease the volume of the digester and hence will reduce its efficiency. The accumulation of inert and non-degradable material makes it necessary to stop the process from time to time and remove the materials, thereby increasing labour and maintenance cost of the technology.

There is also lack of adequate coordinating framework as one of the most important weakness of energy institutions in Africa. Lack of coordination among institutions and conflicting interests are obstacles to good penetration of biogas technology into the African market. Rationalising functions and building institutions around them will improve the situation (Davidson, 1992). Constant persuasion and active campaigns can help reduce institutional inertia and resistance to adoption of biogas technology. Most renewable energy technologies require long development periods and dedicated stakeholders are important for building up experiences and competencies. New technologies often need to be nurtured for over decades, before sufficient socio-technical momentum emerges. Alignment between the technical, economic, regulatory and social context can provide the basis for building up momentum, until the biogas technology is able to survive on its own. Many African countries have a National programme having a three-pronged focus: sanitation, rural energy, and organic fertilizer usage, aimed at promoting domestic and agricultural based plants and this will help in promoting and implementing biogas plants. There are also now many biogas service providers in many African countries that specialize in the construction of biogas plants. The major focus of the biogas service providers is on sanitation. The service providers have used the hygiene-promoting aspect of biogas plants to market the technology.

There is need for continuous improvement of the biogas technology because its implementation is intrinsically the exploitation of the technical advantages. In some instances biogas plants have not worked effectively because of lack of support, lack of repairs and poor design. Lack of knowledge about biogas technology is often cited as a reason for non-adoption of biogas in some countries in Africa. Where people have installed biogas reactors, problems arising from the bad quality of the installed units and the poor operations and maintenance capacity of users have led to poor performance and even abandonment of biogas digesters. In some instance, the demonstration effect has been one of failure and has served to deter rather than enhance biogas adoption. A survey in Kenya of about 21 existing plants in 1986 found only 8 out of 21 functional and 13 out of 21 not functional or never finished (Day et al., 1990). According to the authors, the major problems 
associated with existing biogas plants in Kenya include inadequate design and construction, poor maintenance, and poor social acceptance. The effect of individual economic status is also important to consider in the assessments of biogas technology. Ni and Nyns (1996) reported that most surveys have revealed that biogas is more accepted by upper and middle-income farmers. The obvious effect of the income of individuals is the ability of investment to install a digester system and above all to maintain it operational. The regular operation of a biogas plant is more difficult to achieve than its initial installation. The routine operation and maintenance of the digester system need much physical work that is usually laborious and messy, making the biogas benefits less attractive.

\subsubsection{Other factors affecting biogas production and commercialisation}

The site-specific issues that have limited the scope of biogas technology in sub-Saharan Africa include the availability of water and organic materials for effective biodigester operation. Limited water availability poses a constraint for biogas operation in some countries because biogas plants typically require water and substrates such as manure to be mixed in an equal ratio. Small-scale farmers frequently lack sufficient domestic animals to obtain enough manure for the biodigester to produce sufficient gas for lighting and cooking. Even where households keep sufficient numbers of animals, semi nomadic or the free grazing system of many communities in sub-Saharan Africa makes it difficult to collect dung to feed digesters (Abbey, 2005). In countries where houses are clustered together as in Nigeria, a community plant might be more feasible (Akinbami et al., 2001).

In assessing the economic viability of biogas projects one should distinguish four major areas of applications: individual household units, community plants, large-scale commercial plants and industrial plants. In each of these cases, the financial feasibility of the facility depends largely on whether outputs in the form of gas and slurry can substitute for costly feeds which were previously purchased, the efficiencies with which the fuel is used or possible equipment which could lead to higher efficiencies. If 'externalities' such as employment, import substitution, energy security, environmental protection, and so on are considered then the economics change usually in favour of the biogas technology (Hall et al., 1992).

All too often, projects intended to introduce new energy technologies are conceived without proper understanding of the needs, problems, capabilities and priorities of the targeted users. Most of the Chinese and Indian biogas plants introduced in Africa are not functional due to many reasons. One of the major reasons of the failure is the separation of national interests and individual family/community interests (Ni and Nyns, 1996). There is need to learn from the past experiences and adapt the biogas technology from Europe and Asia for local African circumstances. There is also the need for bottom-up approach that takes the user interest into account. The Botswana biogas water pumping programme of the mid1980s is a good example of how a misunderstanding of the target communities' needs and problems lead to project failure. The Botswana government's effort was to introduce biogas as the main pumping fuel in some areas. Water supply is a priority in Botswana due to its arid climate. The problems that arose were not technical but rather socio-economic. The villages targeted to 'benefit' from the biogas-pumped water felt disadvantaged in that they had to pay for the water they collected with cattle dung while other villages paid nothing by 
using the usual government or donor-supplied diesel engines. The benefits of biogas were important to the government as a means of reducing dependence on imported diesel. The perception from the point of view of the intended project beneficiaries was different. Today the biogas plants are disused. The principal reason is that real acceptance of the biogas technology depends on individual interests that do not totally respond to those at the national level. This suggests the necessity of understanding fully the individual interests of a project.

Renewable energy projects conceived without carefully consulting the intended recipients and beneficiaries face serious acceptance problems and fail prematurely due to abandonment. Numerous large-scale demonstration projects such as a sophisticated integrated biogas engine generator system at Kushinga Phikelela near Marondera in Zimbabwe collapsed when weaned from donor support. The reasons of failure had mainly to do with supply of spare parts which had to be procured with scarce foreign currency and lack of local capacity and funds to maintain demonstration installation. The host institute did not need the biogas technology since it has grid electricity and hence neglected it.

Some potential users are reluctant to try the biogas digesters out of concern about sanitation. Use of human wastes from for biogas production and the subsequent digested sludge, for example in schools, as a source of fertiliser faces cultural and health resistance. Even though the anaerobic digestion process naturally reduces the pathogen load, handling biogas feedstock particularly human excreta and using biogas slurry as fertiliser does pose some risk of infection (Brown, 2006). A major difficulty is utilising manure sources properly. There is usually lack of enough supply of manure for efficient and sustainable biogas production. Liquid manure is preferred for most biogas plants, but households may not be accustomed to storing and handling it. People also find it difficult to collect, store and deliver fresh manure to the digester. Liquid manure must be stored in pits or other installations that require investment of time and labour. Therefore promotion of liquid manure digesters requires additional education and training to ensure sustainability. The problems also include that animals must be penned for effective collection of animal dung, farmers must own a sufficient number of livestock to generate continuous flows of biogas, and the initial costs for the required infrastructure may be deterrent (Karekezi, 1994b). The effort of maintenance and control on biogas plants often does not meet the level of literacy skills of rural population.

It is also important to realise that lack of information on improved technologies such as biogas technology at all levels, government, energy institutions, and consumers, poses a very serious problem for technology penetration. Poor infrastructures prevent access to even the vast information available in the public domain about biogas technology and its application. Generating interest among the various stakeholders and setting up information systems using relatively cheap devices now available can assist greatly. Setting up or strengthening existing information systems is very important for the use of renewable energy technologies such as biogas. These systems should be capable of coordinating energy and energy-related information activities with appropriate means for collection, filtering, storage, retrieval and dissemination. In order to promote the implementation and proper use of anaerobic digestion technology, it is important to initiate long-term anaerobic digestion and other renewable energy training and capacity-building programmes, and to perform scientific work in this field (through appropriate research). It is important to 
establish contacts between research and university groups and experienced contractors, and to initiate collaboration with polluting industries, i.e., to interest them in the system, either for use as an environmental protection method, or for energy production. In addition, experts should provide reliable and pertinent information about the biogas technology and its potential to local authorities, politicians, and the public in general. It demands a lot of efforts in achieving an efficient transfer of knowledge from research centres and universities to state sanitation companies, consulting engineers firms and government environmental control agencies. There is also need and to obtain grants from the government or international organisations, and industry for pilot-plant and/or demonstration-scale projects (Foresti, 2001; Karekezi, 1994a).

To overcome some of the socio-cultural barriers, intensive educational and campaign programmes may have to be mounted to raise the awareness consciousness of the benefits of this technology. A case in point is that of a full-scale digester installed to treat opaque beer brewery wastewater in Harare which is just being used to treat the wastewater but the biogas from plant is currently vented to the atmosphere (Parawira et al., 2005). Further benefits of the plant could be realised by tapping the energy generated by the anaerobic process in the form of methane.

\subsection{Possible measures to improve biogas production and commercialisation}

The economics of large-scale biogas plants, probably to serve communities, could also be investigated since they may have a much higher benefit-cost ratio compared to family sized plants. In order to launch commercial biogas systems in Africa, it is therefore necessary to introduce incentives in the form of policies, legislation, taxes and financial subsidies and weaken the barriers. This has been the practice in India, China and even in European countries. Presumably community biogas plants which permit higher efficiency rather than household plants should be set up than family units in rural communities. The chances of success of a village biogas plant would be higher for villages with clustered dwellings rather than with dwellings scattered over large distances.

A list summarising the priority issues which must be tackled by most African nation for the development of biogas technology is given in Table 5 .

- Evaluation or re-evaluation of the energy demand and supply patterns and their sectoral distributions at national level in order to estimate the contribution of biogas technology and other renewable energy make to the nation.

- Assessment of the potential of new and renewable energy sources such as biogas so as to tailor their use to the actual needs, and to substitute them for conventional sources wherever appropriate.

- Support of investigations, application, development, training and demonstration for the development of biogas technology.

- Establishment of a technical and scientific information network connected with international sources to diffuse the latest technological advances and applications, and enhancement of the research in accordance with national needs.

- Encouragement of joint research and development activities of mutual benefit.

- Organisation of a number of demonstration and pilot projects to illustrate the potential of new and renewable sources and to disseminate technological information. 
- Provision of several economic incentives to accelerate and increase the biogas applications in the country Preparation of large scale projects to obtain support from non-profit international organisations and agencies such as United Nations, World Bank, Organization of Arab Petroleum Exporting Countries (OAPEC), Islamic Foundation for Science, Technology and Development (IFSTAD, Jordan), etc.

- Increasing public awareness of biogas technology by distributing simple explanatory pamphlets or using other media.

- Encouragement of potential private investors by offering a governmental partnership in the production of biogas technology.

Table 5. Priority issues which must be tackled by African countries for the development of biogas technology.

\subsubsection{Biogas technology research in sub-Saharan countries}

In developing countries, biogas energy research should be planned and conducted as the main factor leading to its contribution to the solution of energy problems. Keeping this in mind, the results of the research should be applicable on a nation-wide scale and constitute a part of the country's development plan. In many of the developing countries, there is remain some basic research areas mostly on the quantity and potential biogas yield of fermentable organic wastes available, the size and type of biogas digesters which can be economically viable for the potential consumers of the biogas technology.

Biogas technology research in selected sub-Saharan African countries has recently been reviewed by Mshandete and Parawira (2009). The review provided an insight and update of the state of biogas technology research in some selected sub-Saharan African countries in peer reviewed literature. An attempt was made to pinpoint future research in critically reviewing the biogas technology research. The methane-producing potential of various agriculturally sourced feedstocks has been researched, as has the advantages of co-digestion to improve carbon-to-nitrogen ratios and the use of pretreatment to improve the hydrolysis rates. Some optimisation techniques associated with anaerobic digestion including basic design considerations of single or two-stage systems, pretreatment, co-digestion, environmental conditions within the reactor such as temperature, $\mathrm{pH}$, buffering capacity have been attempted in some of the researches in Nigeria, Tanzania, and Zimbabwe. However, there appears to be little research in biogas technology in many sub-Saharan African countries in internationally peer reviewed literature. However, biogas technology research will only have an impact if relevant and appropriate areas of research are identified and prioritised.

\section{Gender implication of rural energy technology}

Generally, rural women are greatly involved in managing household energy systems. Rural women are also the ones who are directly affected by the rural energy crisis. As mentioned in previous sections, traditional firewood cooking causes faster depletion of biomass resources and increases the time that women require in collecting firewood. These activities consume a great deal of the time and labour of women and increase the drudgery of women. In addition, the use of traditional energy technologies has a negative impact on women's health due to the smoke from firewood and their heavy workload. There is 
therefore the need for an intervention, that help to reduce women's labour and time, which could be used for other productive purposes, and to improve the health conditions of women. In this regards, an intervention with anaerobic digestion is needed. Such an intervention should be based on gender concerns both at macro and micro levels in terms of recognizing women's roles and responsibilities and their priorities regarding rural energy. The focus should be on reducing expenditure of human energy rather than only saving fuel. Hence, it is very important here to consider the practical gender needs, which fulfil the regular energy needs at household level while saving the time and labour of women, and the strategic gender needs, which provides the opportunities for women to be involved in social and economic activities for their self-enhancement and empowerment.

\subsection{Biogas in rural communities and its benefit}

Households in Africa, particularly in the rural areas are increasingly facing energy supply problems. According to United Nations (2010) there are approximately 60\% of the total African population living in the rural areas. Biomass in form of wood, cow dung, and crop residues biomass constitutes $30 \%$ of the energy used in Africa and over $80 \%$ used in many sub-Saharan countries such as Burundi (91\%), Rwanda and Central Africa Republic (90\%), Mozambique (89 \%), Burkina Faso (87\%), Benin (86\%), Madagascar and Niger (85\%) (cited in United Nations Economic and Social Council, 2007). The availableness of these traditional fuels (wood, dried dung and agricultural waste) is declining (Deutsche Gesellschaft für Internationale Zusammenarbeit (GIZ) GmbH and Integrated Science and Technology ISAT, undated), while the commercialised fuels (e.g. charcoal) are very expensive and their availability unreliable. Domestic biogas provides an opportunity to overcome these challenges in the rural areas. This is because biogas production makes use of domestic resources such as agricultural crop wastes and animal wastes such as pigs, cattle, and poultry as well as human excreta. Biogas production using the existing domestic resources therefore, has a potential to provide a number of benefits to the rural communities in Africa. Biogas plants that are well functioning can provide a wide range of direct benefits to the users particularly in the rural areas. Many of these benefits are directly linked to the Millennium Development Goals of reducing income poverty, promoting gender quality, promoting health and environmental sustainability.

\subsubsection{Renewable energy generation}

The bulk of the rural population in Africa have no access to electricity. According to World Economic Outlook (2010), only 14\% of sub-Saharan African has access to electricity. It is thus estimated that 582 million rural people in sub-Saharan Africa did not have access to electricity in 2009 (World Economic Outlook, 2010). North Africa is an exception because $98.4 \%$ of rural population is electrified and only 2 million did not have access to electricity in 2009 (World Economic Outlook, 2010). Biogas is a potential off-grid, clean energy fuel solution for rural areas of Africa (Amigun and von Blottnitz, 2010), that can provide energy services such as cooking, heating and lighting.

\subsubsection{Environmental benefits}

Fuel wood consumption is often portrayed as a cause of environmental degradation, and may lead to energy insecurity for rural African households, especially where the resource is 
commercialized (Hiemstra-van der Horst and Hovorka, 2009). The high dependence on woodfuel in the sub-Saharan Africa has resulted in an alarming rate of tree felling and deforestation (cited in United Nations Economic and Social Council, 2007). According to the United Nations Environmental Programme (2011), nearly half of the forest loss in Africa is due to removal of wood fuel. The estimated deforestation rate in Africa is twice the world rate (AfriNews, 2008). More than 15 million hectares of tropical forests are depleted or burnt every year in order to provide for small-scale agriculture or cattle ranching or for use as fuel wood for heating and cooking (United Nations Convention to Combat Desertification, 2004). Some alarming and worrying deforestation facts in Africa include (AfriNews, 2008): loss of over $90 \%$ of West Africa's original forest - currently, only a small proportion remains; between 1980 and 1995, an area of 1.1 million ha was cleared every year; only one tree is replanted for every 28 trees cut down. In Uganda where $90 \%$ of the population lives in rural areas and directly depends on land for cultivation and grazing, forestland has shrunk dramatically. In Nigeria, it is feared that the country will be left without forest due to the present level of deforestation activities.

Forests are required in order to build a resilient natural ecosystem as they moderate climate, act as water reservoirs and are habitat to wildlife. The loss of ground cover due to deforestation thus results in secondary problems such as exposing the soil to erosion during heavy rainfall, flooding, increased evaporation, drought, and increase in the greenhouse gas emissions. Familiar country specific example is the recent frequent droughts and floods experienced in East African countries, particularly Kenya, Somali, Uganda and Ethiopia, that have been associated with deforestation (IRIN, 2006; Mekonnen, 2006). Similarly, the declining rainfall in the West African countries is also attributed to deforestation. The use of alternative energy such as biogas has a potential to reduce the demand for wood and charcoal use, hence reducing greenhouse gas emissions improving water quality, conserving of resources - particularly trees and forests - and producing wider macroeconomic benefits to the nation (Amigun and Blottnitz, 2010) due to reduced deforestation. In addition, the slurry and waste from the biogas plants provides a high quality fertiliser that can be used to improve the soil fertility and increase productivity in agriculture dependent rural communities in Africa.

\subsubsection{Improving quality of life in rural areas}

The use of biogas has a potential improve the quality of life in the rural areas through reduced drudgery in women and children, reduced indoor smoke, improved sanitation and better lighting (Amigun and Blottnitz, 2011). Wood fuel gathering is a hard and time consuming duty for women. For instance, it is estimated that women can spend 2-6 hours in collecting wood fuel (DFID, 2002) depending on the country and region. For instance, one study in Limpopo, South Africa found that the rural women spend 5-6 hours (Masekoameng et al., 2005), while another study in a different region of South Africa report that the women spend over two hours. This takes away time that could be better utilized in other productive activities such as income generation or education particularly for girls who have to be absent from school to undertake such task. Biogas plants thus can help in reducing the workload of women and girls in collecting firewood.

Burning traditional fuel releases smoke which contains toxic pollutants such as carbon monoxide, hydrocarbons and particulate matter (Smith et al., 2005). Some of the prevalent 
health problems caused by the smoke inherent to traditional ways of cooking and heating, particularly open fires include: sneezing, nausea, headache, dizziness, eye irritation and respiratory illnesses (Onguntoke et al., 2010). Biogas improves health of the rural people by providing a cleaner cooking fuel thus avoiding these health problems. Women and children have the greatest risk of these health problems and children under 5 years are at high risk of contracting acute respiratory illnesses such as, pneumonia. Often, the rural population are also faced with lack of sanitation, resulting in water borne diseases affecting mainly women and children. Operating a biogas plant implies that manure is directly fed to the plant keeping the kitchen smoke free and farmyard cleaner.

\subsection{Lesson from some biogas initiatives (case studies) in Africa}

As indicated in Table 3, there are some digesters have been installed in a number of subSaharan Africa. These have mainly been pilot or demonstration projects aimed at testing the technical viability of small-scale biogas technology at a limited scale (Hivos, 2009a). These pilot projects have mostly been funded by non-governmental organizations and built for health clinics, schools, and small-scale farmers. While the small-scale biogas plants are located throughout Africa, only a few of them are operational (Parawira, 2009). There is also limited documentation on whether the existing biogas digesters have been successful in achieving the benefits highlighted in section 3.1. Some country specific examples is Tanzania, Ivory Cost and Burundi, which have produced biogas from animal and human waste using the Chinese fixed-dome digester and the Indian floating-cover digester (Omer and Fadalla, 2003). These have not been reliable and in many cases, poor performance has been reported (Omer and Fadalla, 2003). Thus, the plants have only operated for a short period due to poor technical quality (Mshandate and Parawira, 2009).

Currently, a number of different organizations are establishing biogas initiatives in Africa, particularly in rural areas, in order to supply cleaner burning energy solutions. These initiatives are at different stages of development such as: prefeasibility, feasibility, design and implementation to a limited extent. For instance, Burkard (2009) reports on five biogas case studies in Kenya which were to utilize agricultural leaves, residues from floriculture, and residues from vegetable production and canning. In 2010, it was reported that the Dutch government was to spend 200 million Kenyan Shilling to set up 8000 biogas digesters throughout the country. The initiative was targeting farmers practising zero grazing (Daily Nation, 2010). Similar projects are being implemented in Ethiopia, Uganda, Senegal, Burkina Faso, and Tanzania. There are also some other initiatives such as biogas for better life, which is at various stages of biogas development in Ethiopia, Kenya, Uganda, Sudan, Zambia, Malawi, South Africa, Lesotho, Swaziland, Mali, Senegal, and Ghana ${ }^{1}$. The Netherland Development Organization (SNV) has been supporting the development of National Biogas programmes in East Africa (Ethiopia, Kenya, Uganda, Tanzania, Rwanda) and West Africa (Senegal and Burkina Faso)2. While there are few documented successful small-scale biogas plants in the rural areas of Africa, this section will present some selected country specific biogas projects.

\footnotetext{
${ }^{1} \mathrm{http}: / /$ www.biogasafrica.org/

${ }^{2}$ http://www.snvworld.org/en/ourwork/Pages/Renewable\%20Energy.aspx
} 


\subsubsection{Rwanda}

Rwanda has a population of 10.2 million people of which $81 \%$ of this population reside in the rural areas in 2010 (United Nations, 2007). One of the famous biogas programmes is the Kigali Institute of Science and Technology (KIST) large-scale biogas plants developed and installed in prisons. The aim of these plants was to treat toilet wastes and generate biogas for cooking. The first plant prison which was operational in 2001, and by 2011, KIST has managed to build and operationalize biogas plants in 10 prisons. Each prison is supplied with a linked series of underground biogas digesters, in which the waste decomposes to produce biogas. After this treatment, the bio-effluent is safe to be used as fertiliser for production of crops and fuel wood. The project was funded by Red Cross and the plant consists of five interlocking chambers. KIST's project saves $50 \%$ of wood for cooking and it won Ashden Award in 2006. The projects construction is managed by KIST, who also provides training to both civilians and prisoners.

Another biogas programme is the National Biogas Programme which is promoted by the Rwanda Ministry of Infrastructure, through the support by the Netherlands development organization. The programme aims at reducing firewood use by the households. The Ministry of Infrastructure estimates that 441 units have been installed to date, and approximately 15000 households will be using biogas by end of 2011 for cooking and lighting ${ }^{3}$. The Ministry of Infrastructure of Rwanda is also collaborating with other ministries (e.g. Ministry of Education) in order to develop biogas plants in schools, clinics and community institutions.

\subsubsection{Ghana}

Ghana has a population of 24.8 million of which $48.5 \%$ live in the rural areas (United Nations, 2007). Netherlands Development Organization (2007) estimates that Ghana has a potential to realise 280000 domestic biogas plants, that is capable of producing $6000 \mathrm{~m}^{3}$ of liquid fertiliser, which would increase yield by $25 \%$. However, low perception of biogas has modern energy has made Ghana not to realise the full potential of biogas utilisation (Bensah and Brew-Hammond, 2008). Bensah and Brew-Hammond (2010) highlights the status of the biogas development in Ghana, in which only about 200 units have been installed, thus lagging behind in comparison with other African countries such as Rwanda, Kenya and Tanzania. Some initiatives such as Biogas Technology West Africa Ltd ${ }^{4}$, funded by UNIDO has implemented a number of biogas digesters in Ghana for schools, hospitals and colleges. These are mainly underground masonry dome systems in the range of $60 \mathrm{~m}^{3}$ to $160 \mathrm{~m}^{3}$ volume. One example of these projects is Keta secondary school plant for 1200 users, and has a capacity of $80 \mathrm{~m}^{3}$. The plant is built in sandy, water logged area and it makes use of human waste. The gas is used for cooking. The future development of biogas in Ghana will however not be left to private investors and initiatives if the benefit to the rural communities is to be realised. Bensah and Brew-Hammond (2010) argues that, for successful future development of biogas in Ghana, there is a need for establishing a government body that solely focuses on promoting biogas.

\footnotetext{
${ }^{3} \mathrm{http}: / /$ mininfra.gov.rw/index.php?option=com_content\&task=view\&id=115\&Itemid=143

${ }^{4} \mathrm{http}: / /$ www.biogasonline.com/projects.asp
} 


\subsubsection{Mozambique}

Mozambique has a population of 22.6 million people, in which $61.6 \%$ reside in rural area in 2010 (United Nations, 2007). Similar to Ghana, the Mozambique government does not have an agency solely supporting the development of biogas. Some initiative such as Biogas Technology West Africa $\operatorname{Ltd}^{5}$ is however, also undertaking a biogas power project in the country. The project is an electric power system powered by a biogas-fired internal combustion engine generator at Mpunsa Village, Chicualacuala District, Gaza Province in Mozambique.

\subsubsection{South Africa}

Philippi biogas project is funded by the working for energy programme of South Africa, and it is situated in horticultural area zoned as agricultural land ${ }^{6}$. Two digesters have been constructed on site and each of them is $10 \mathrm{~m}^{3}$. The total plant capacity could $12000-15000$ litres of biogas per batch load. This is equivalent to $25 \mathrm{kw}$ per batch or more than 100 hours of cooking time. This project is still in its early stages of implementation.

\subsubsection{Tanzania}

Tanzania has a population of 42.5 million people of which $75 \%$ live in the rural area (United Nations, 2007). This is one of the countries that has progressed well in terms of biogas development and has several case studies. The first one is in the region of Tanga, which is known for sisal production as a cash crop. The sisal is sold to a number of sisal processing companies to produce fibre. Using the available production methods, only $4 \%$ of the sisal biomass is recovered as fibre and the rest is waste, which is either burnt, producing carbon dioxide or left to decompose, producing Methane (The Bioenergy Site, 2009). Utilising sisal waste for bioenergy can thus be environmentally beneficial since $80 \%$ of the plant mass is suitable for biogas production, and can also increase profit to the sisal growing farmers (The Bioenergy Site, 2009). With this opportunity in place, UNIDO, through its initiative on "Rural Energy for productive use" established a biogas pilot demonstration project, with the support from Common Fund for Commodities (CFC) 7 . The plant situated at the Katani Sisal estate in Hale, and utilises the sisal waste generated from the sisal processing plant. The biogas power plant has installed capacity of $300 \mathrm{~kW}$, and was inaugurated by the Tanzanian President in 2008 (UNIDO, 2008). The electricity generated from this plant is used for lighting and running small-scale industries. The company, Katani Limited, also provides energy services to local schools and hospitals in the area (PISCES and FAO, 2009). The company currently plans to expand the capacity to $7000 \mathrm{~kW}$ that will be connected to the grid (The East African, 2011).

A Tanzanian Domestic Biogas programme was also initiated in 2007, following a feasibility study by the GTZ. The programme set an ambitious goal of developing 3500 to 4000 units per annum. However, it was estimated that the current construction rate is only 200 to 400 per year (Sika, 2010).

\footnotetext{
${ }^{5} \mathrm{http}: / /$ www.biogasonline.com/projects.asp

${ }^{6} \mathrm{http}: / /$ www.smart2energy.co.za/index.php/pilot-projects/western-cape

${ }^{7}$ http:/ / www.unido.org/index.php?id=6464
} 


\subsubsection{Kenya}

Kenya has population of 40.6 million people, of which $77.8 \%$ reside in the rural areas (United Nations, 2007). Kenya similarly has a programme for promoting domestic biogas development, in which the Kenya National Federation of Agricultural Producer is the implementing agency ${ }^{8}$. The programme targets to install 8000 domestic biogas plants of between $6 \mathrm{~m}^{3}-12 \mathrm{~m}^{3}$ capacity by 2013, and prioritizes the high agricultural potential regions. A number of demonstration plants have currently been constructed and launched.

\subsubsection{Ethiopia}

Ethiopia has a population of 89.6 million people, of which $82.4 \%$ live in the rural areas (United Nations, 2007). Through the Ethiopia Rural Energy Development and Promotion Centre (EREDPC) the National Biogas Program (NBP) was also launched. The aim of the programme is to establish 14000 biogas plants between 2008 and 2012, in four regions of Ethiopia (EREDPC, 2008). The NBP utilises cattle manure as the feedstock for biogas production (EREDPC, 2008). In 2009, some households had already started experiencing the benefits of the project such as: use of clean cooking fuel; income savings made in terms of time and money to search for fuel and purchase other traditional fuels (wood, charcoal and kerosene) respectively; and income generation from the sale of biogas to the neighbouring towns (Hivos, 2009b).

\section{Biogas economics}

The economy of a biogas plant is characterised by initial high investments costs, some operation and maintenance costs, mostly free raw materials (animal dung, aquatic weeds, terrestrial plants, sewage sludge, industrial wastes, poultry litter etc.) and income from the sale of biogas or electricity and heat (Amigun and von Blottnitz, 2007). Sometimes, other values can be added, e.g. for improved value of sludge as a fertilizer. The installation cost of a typical biogas plant is site specific (it depends on the topography of the area, labour cost at the site location, community participation, learning curve, use of the biogas product). Also, the economic performance of a biogas system will be very site specific and will depend on current markets for the input and outputs, the nature of agricultural practices and the system of organisation adopted by the community involved (Taleghani and Kia, 2005).

Good understanding of the relation between capital costs and plant size can provide useful information in assessing economic viability of biogas plants, and providing means whereby decisions are taken on developmental of a new project. In a developing economy, local market opportunities frequently restrict the size of a process plants. Scale effects influence costs per unit of capacity (specific cost). The scale economies concept is therefore of key concern because it can help in determining the optimal size of a biogas digester (Amigun and von Blottnitz, 2010).

Higher capital cost is experienced in African biogas industry. This is due to the fact that the current market for biogas in Africa is slow. Contractors therefore tend to lump all of their

\footnotetext{
${ }^{8}$ http:/ / www.kenfapbiogas.org/index.php?option=com_content\& view $=$ category\&layout $=$ blog\&id $=36 \&$ Itemid $=57$
} 
costs into the unit they are constructing because they may not get another order for months (Biogas for better life, 2007). Biogas technology in Africa appears to be implemented by technologically driven oligopolies - an economic situation where there are so few suppliers of a particular product that one supplier's action can have a significant impact on price and its competitors (Butare, 2005; Cawood, 2006, Mojaki Biogas Technology, 2008). The price which the typical firm charges depends on the number of firms in the industry. The less the number of suppliers, the less the competition, and hence the higher the charge. This concept is represented in the equation 1. The higher capital cost experienced in African biogas industry is aggravated by the fact that the current market for biogas in Africa is slow. Contractors therefore tend to lump all of their costs into the unit they are constructing because they may not get another order for months (Biogas for better life, 2007).

$$
Q=(S / n+S \times b \times \bar{P})-S \times b \times P
$$

where:

$Q=$ firm sales; $S=$ total sales of the industry; $n=$ number of firms in the industry;

$b=$ constant term representing the responsiveness of a firm's sales to its price;

$P=$ price charged by the firm itself; $\bar{P}=$ average price charged by its competitors.

Substantial cost reduction could be obtained through design optimisations and efficiencies created through economies of scale, as well as smart implementation and planning. In planning, the concept of clustering installations, where a number of orders for digesters within a defined geographic area would accumulate until a threshold is reached could provide substantial reduction of costs.

There is evidence that higher location factors are partly due to the need of importing specialized equipment (World Bank, 2007). In heavily industrialized countries, the equipment is often fabricated in the same area where the plant is constructed; in developing countries, depending on level of technology needed, equipment is generally imported along with specialised personnel to install it, at premium prices leading to increased investment costs. The investment costs are believed to be affected by the geographical location of the country viz: coastal and landlocked locations. However, a recent report by Amigun and von Blottnitz (2010) on the influence of geographical location (coastal and landlocked biogas plants) on biogas economics revealed that the cost of biogas technology is largely independent of geographical location of the plant, which is probably explained by the use of local construction materials in most small-medium scale biogas plants in Africa. The lower the import content of the total plant costs (for example, amount of steel), the less the external diseconomies which may arise in consequence of sliding exchange rates and transportation construction of materials.

\section{Conclusion}

Biogas technology represents one of a number of village-scale technologies that offer the technical possibility of more decentralised approaches to development. In addition, this technology offers a very attractive route to utilise certain categories of biomass such as agricultural organic waste or manure in rural areas for partially meeting energy needs (e.g. heating, electricity). This technology can therefore serve as a means to overcome energy 
poverty which poses a constant barrier to social and economic development in developing countries such as Africa.

Biogas initiatives in Africa is characterised by small to medium scale plants. Biogas technology is however, still beyond the reach of rural poor due to its high initial investment costs. There also exist a number of constraints affecting the implementation of the biogas technology on large scale such as: political, social-cultural, financial, informational, institutional, technical and training constraints. Priority issues which must be tackled by African countries for the development of biogas technology include: evaluation or reevaluation of the energy demand and supply patterns and their sectoral distributions at national level in order to estimate the contribution of biogas technology and other renewable energy make to the nation; assessment of the potential of new and renewable energy sources such as biogas so as to tailor their use to the actual needs, and to substitute them for conventional sources wherever appropriate; support of investigations, application, development, training and demonstration for the development of biogas technology.

Sub-Saharan Africa with its warm climates is well-suited for the biogas digester technology. However, it is very important to consider the practical gender needs, which fulfil the regular energy needs at household level while saving the time and labour of women, and the strategic gender needs, which provides the opportunities for women to be involved in social and economic activities for their self-enhancement and empowerment at the planning phase of biogas development.

\section{References}

Abbey, A.T. 2005. Biogas in Uganda: A new experience. Leisa, 21:13-15

AfriNews 2008. Deforestation reaches worrying level - UN. http://www.africanews.com/site/list_messages/18831 [accessed 2 October 2011].

Ahring B, Angelidaki I, Johansen K. 1992.Anaerobic treatment of manure together with industrial waste. Water Science Technology,25:311-318.

Akinbami J.-F.K., Ilori M.O., Oyebisi T.O., Akinwuni I.O., Adeoti O. 2001. Biogas energy use in Nigeria: current status, future prospects and policy implications. Renewable and Sustainable Energy Reviews, 5:97-112.

Akinbami J.-F.K., Salami, A.T., Siyanbola, W.O. 2003. An integrated strategy for sustainable forest-energy-environment interactions in Nigeria. Journal of environmental Management, 69:115-128.

Amigun B., Sigamoney R., von Blottnitz H. 2008. Commercialisation of biofuel industry in Africa: A review. Renewable and Sustainable Energy Reviews, 12:690-711.

Amigun B., von Blottnitz H. 2007. Investigation of scale economies for African biogas installations. Energy Conversion and Management, 48:3090-3094.

Amigun, b. von Blottnitz, H. 2010. Capacity-cost and location-cost analyses for biogas plants in Africa. Resources, Conservation and Recycling, 55, 63-73.

Angelidaki, I., Boe, K. and Ellegaard L. 2004 Effect of operating conditions and reactor configuration on efficiency of full-scale biogas plants. Proceedings of the $10^{\text {th }}$ World Congress in Anaerobic Digestion, Montreal Canada, 29th August-2nd September.

Angelidaki, I., and Ellegaard L. 2003. Co digestion of manure and organic wastes in centralised biogas plants. Applied Biochemistry and Biotechnology, 109:95-105. 
Ayalon, O., Avnimelech, Y., and Shechter, M. 2001 Solid waste treatment as a high-priority and low-cost alternative for greenhouse gas mitigation. Environmental Management, 27, 697-704.

Barber, W.P. and Stuckey, D.C. 1999 The use of anaerobic baffled reactor (ABR) for wastewater treatment: A Review. Water Research, 33, 1559 -1578.

Bensah E. C and Brew-Hammond, A .2008. Biogas effluent and food production in Ghana. 4th National Conference of Ghana Society of Agricultural Engineering. http://energycenter.knust.edu.gh/downloads/6/64.pdf [accessed 10 October 2011].

Bensah E. C and Brew-Hammond, A. 2010. Biogas technology dissemination in Ghana: history, current status, future prospects, and policy significance. International Journal of Energy and Environment, 1: 277-294.

Björnsson, L., Mattiasson, B. and Henrysson, T. 1997 Effects of support material on the pattern of volatile fatty acid accumulation at overload in anaerobic digestion of semi-solid waste. Applied Microbiology and Biotechnology, 47, 640-644.

Borja, R., Martin, A., Luque, M., and Alonso, V. 1994 Kinetics of methane production from wine distillery wastewater in an immobilized cell bioreactor using sepiolite as support medium. Resources Conservation and Recycling, 10, 317-327.

Bouallagui, H., Cheikh, R.B., Marouuani, L. and Hamdi M. 2003. Mesophilic biogas production from fruit and vegetable waste in tubular digester. Bioresource Technology, 86, 85-89.

Brown, V. 2006. Biogas: a bright idea for Africa. Environmental Health Perspectives, 114:300303.

Brummeler, E.T. 2000 Full scale experience with the BIOCEL process. Water Science and Technology, 41, 299-304.

Burkard T.2009. Project cases of biogas-plants in Kenya. http:/ / www.akut-umwelt.de/bin/news/AKUT-Project-cases-in-Kenya.pdf [accessed 29 September 2011].

Callaghan, F.J, Luecke K, Wase, D.A.J, Thayanithy K., Forster, C.F. 1997. Co-digestion of cattle slurry and waste milk under shock loading conditions. Journal Chemical Technology and Biotechnology,68:405- 410.

Callaghan, F,J, Wase D,A,J, Thayanithy K, Forster C,F. 2002. Continuous co-digestion of cattle slurry with fruit and vegetable wastes and chicken manure. Biomass Bioenergy;27:71-77.

Chynoweth, D.P., Owens, J.M. and Legrand R. 2001 Renewable methane from anaerobic digestion of biomass. Renewable Energy, 22, 1-8.

Daily Nation 2010. Kenya: Dutch to inject Sh200 million into biogas project, 27 May. http:/ / allafrica.com/stories/201005271360.html [accessed 28 September 2011].

DFID 2002. Energy for the poor.

http://www.ecn.nl/fileadmin/ecn/units/bs/JEPP/energyforthepoor.pdf [accessed 29 September 2011].

Davidson, O. R. 1992. Energy issues in Sub-Saharan Africa: Future Directions. Annual Reviews Energy Environment 17:359-403.

Day, D.L., Chen, T.H., Anderson, J.C., Steinberg, M.P. 1990. Biogas plants for small farms in Kenya. Biomass 21:83-99. 
de Baere, L. 2000 Anaerobic digestion of solid waste: state of the art. Water Science and Technology, 41, 283-290.

Edelmann, W., Schleiss, K. and Joss, A. 2000 Ecological, energetic and economic comparison of anaerobic digestion with different competing technologies to treat biogenic wastes. Water Science and Technology, 41, 263-273.

EREDPC 2008. National Biogas Programme Ethiopia. Programme Implementation Document.

http://www.snvworld.org/en/Documents/NBP_implementation_document_Ethi opia_2008.pdf [accessed 10 October 2011].

Francese A.P., Aboagye-Mathiesen G., Olesen T., Co'rdoba P.R. and Sineriz F. 2000 Feeding approaches for biogas production from animal wastes and industrial effluents. World Journal of Biotechnology, 16:147-150.

Foresti, E. 2001. Perspectives on anaerobic treatment in developing countries. Water Science and Technology, 44, 1-6.

Frankin, R.J. 2001. Full-scale experiences with anaerobic treatment of industrial wastewater. Water Science and Technology, 44, 141-148.

Gijzen, H.J. 2001 Anaerobes, aerobes and phototrophs, a winning team for wastewater management. Water Science and Technology, 44, 123-132.

Gijzen, H.J. 2002 Anaerobic digestion for sustainable development: a natural approach. Water Science and Technology, 45, 321-328.

Grommen, R. and W. Verstraete 2002 Environmental biotechnology: the ongoing quest. Journal of Biotechnology, 98(1), 113-123.

GTZ and ISAT (undated). Biogas digest volume 1. http://www.gtz.de/de/dokumente/en-biogas-volume1.pdf[accessed28 September2011].

Gujer, W. and Zehnder, A.J.B. 1983 Conversion processes in anaerobic digestion. Water Science and Technology, 15, 127-167.

Gunaseelan, V.N. 1997 Anaerobic digestion of biomass for methane production: A review. Biomass and Bioenergy, 13, 83-114.

Hall D.O., Rosillo-Calle F., de Groot P. 1992. Lessons from case studies in developing countries. Energy Policy, Janaury:62-73.

Hiemstra-van der Horst, G. Hovorka, A. J. 2009. Fuelwood: The "other" renewable energy source for Africa? Biomass and Bioenergy, 33, 1605-1616.

Hivos 2009a. Africa Biogas Partnership Initiative. http://www.hivos.nl/eng/community/partner/10009895 [accessed 28 September 2011].

Hivos 2009b. Ethiopian households now enjoy the benefit of domestic biogas. http://www.hivos.nl/dut/Users/Members/jmsika/Jean-Marc-Sika/EthiopianHouseholds-now-enjoy-the-benefit-of-domestic-biogas [accessed 10 October 2011].

IRIN 2006. Deforestation exacerbates droughts, floods. 10 November. http://www.irinnews.org/report.aspx?reportid=61528 [accessed 8 October 2011].

Iza, J., Colleeran, E., Paris, J.M. and Wu, W.M. 1991 International workshop on anaerobic treatment technology for municipal and industrial wastewaters: summary paper. Water Science and Technology, 24, 1-7. 
Kaparaju P, Luostarinen S, Kalmari J, Rintala J. 2002. Co-digestion of energy crops and industrial confectionery by-products with cow manure: batch-scale and farm-scale evaluation. Water Science and Technology,45:275-280.

Karekezi S. 1994a. Renewable energy technologies as an option for a low-carbon energy future for developing countries: case examples from Eastern and Southern Africa. International Conference on National Action to Mitigate Global Climate Change. 79 June, Copenhagen, Denmark. Organised by UNEP Collaborating Centre on Energy and Environment.

Karekezi, S. 1994b. Disseminating renewable energy technologies in sub-Saharan Africa. Annual Reviews, 19:387-421.

Kashyap, D.R., Dadhich, K.S. and Sharma, S.K. 2003 Biomethanation under psychrophilic conditions: a review. Bioresource Technology, 87, 147-153.

Kivaisi A.K. and Rubindamayugi, M.S.T. 1996. The potential of agro-industrial residues for production of biogas and electricity in Tanzania. WREC, 917-921.

Laichena J.K., Wafula J.C. 1997. Biogas technology for rural households in Kenya. Organisation of the Petroleum Exporting Countries (OPEC) Energy Review, 21: 223-244.

Lantz, M., Svensson, M., Björnsson, L., and Börjesson, P. 2007. The prospects for an expansion of biogas systems in Sweden - Incentives, barriers and potentials. Energy Policy, 35:1830-1843.

Lema, J.M. and Omil, F. 2001 Anaerobic treatment: a key technology for sustainable management of wastes in Europe. Water Science and Technology, 44, 133-140.

Lissens, G., Vandevivere, P., de Baere, L., Biey, E.M. and Verstraete, W. 2001 Solid waste digesters: process performance and practice for municipal solid waste digestion. Water Science and Technology, 44, 91-102.

Lettinga, G. 1995 Anaerobic digestion and wastewater treatment systems. Antonie van Leeuwenhoek, 67, 3-28.

Lettinga, G., Hulshoff Pol, L.W., Zeeman, G., Field, J., van Lier, J.B., van Buuren, J.C.L. 1997. Anaerobic treatment in sustainable environmental production concepts. In: $8^{\text {th }}$ International Conference on Anaerobic Digestion. Sendai, pp. 32-39.

Lettinga, G. 2001 Digestion and degradation, air for life. Water Science and Technology, 44(8), 157-176.

Lettinga, G. 2004 With anaerobic treatment approach towards a more sustainable and robust environmental protection. In: 10th International Conference on Anaerobic Digestion. Montreal, Canada, 29th August-3rd September, Vol 1 pp. 2-12.

Masekoameng KE, Simaleng TE and Saidi T.2005. Journal of Energy in Southern Africa 3: 4-9.

Mata-Alvarez, J., Macé, S. and Llabre`s, P. 2000 Anaerobic digestion of organic solid wastes. An overview of research achievements and perspectives. Review paper. Bioresource Technology, 74, 3-16.

Mbohwa, C and Fukuda, S. 2003 Electricity from baggasse in Zimbabwe. Biomass and Bioenergy, 25, 197-207.

Mbuligwe, S.E. 2002. Institutional solid waste management practices in developing countries: a case study of three academic institutions in Tanzania. Resources, Conservation and Recycling 35:131-146. 
Mbuligwe S.E., and Kassenga, G.R. 2004. Feasibility and strategies for anaerobic digestion of solid waste for energy production in Dar es Salaam city, Tanzania. Resources, Conservation and Recycling, 42:183-203.

Mekonnen, M 2006. Drought, famine and conflict: the case from the horn of Africa. http://www.beyondintractability.org/case_studies/drought_famine_conflict.jsp?n $\mathrm{id}=6796$ [accessed 9 October, 2011].

Misi S.N, Forster CF. 2001. Batch co-digestion of two component mixtures of agro-wastes. Process Safety and Environment Protection,79(B6):365-371.

Mshandete, A., Björnsson, L., Kivaisi, A.K., Rubindamayugi, M.S.T., and Mattiasson B. 2006. Effect of particle size on biogas yield from sisal fibre waste. Renewable Energy, 31:2385-2392.

Mshandete A. and Parawira W. 2009. Biogas technology research in selected sub-Saharan African countries - a review. African Journal of Biotechnology, 8:116-125.

Mwakaje A.G. 2007. Dairy farming and biogas use in Rungwe district, South-west Tanzania: A study of opportunities and constraints. Renewable and Sustainable Energy Reviews, Article in press.

Murphy, J.T. 2001. Making the energy transition in rural East Africa: Leapfrogging an alternative? Technological Forecasting and Social Change, 68:73-193.

Ni, J. Q., and Nyns, E.J. 1996. New concept for the evaluation of rural biogas management in developing countries. Energy Convers. Mgmt, 37:1525:1534.

Noykova, N., Muller, T.G., Gyllenberg, M., and Timmer, J. 2002 Quantitative analysis of anaerobic wastewater treatment processes: Identifiability and Parameter Estimation. Biotechnology and Bioengineering, 78, 89-103.

Oguntoke O, Opeolu B O and Babatunde N.2010. Indoor air pollution and health risks among rural dwellers in Odeda area, South-Western Nigeria. Ethiopian Journal of Environmental Studies and Management 3: 39-46.

Omer, A. M., and Fadalla, Y. 2003. Biogas energy technology in Sudan. Renewable Energy, 28:499-507.

Parawira W. 2004a. Anaerobic batch digestion of solid potato waste alone and in combination with sugar beet leaves. Renewable Energy, 29:1811-1823.

Parawira W. 2004b. Anaerobic treatment of agricultural residues and wastewater: Application of high-rate reactors. Doctoral dissertation, Department of Biotechnology, Lund University, Sweden ISBN: 91-89627-28-8.

Parawira, W., Kudita, I., Nyandoroh M.G., Zvauya, R. 2005. A study of industrial anaerobic treatment of opaque beer brewery wastewater in a tropical climate using a full-scale UASB reactor seeded with activated sludge. Process Biochemistry, 40:593-599.

Parawira, W., Murto, M., Read, J.S. and Mattiasson, B. 2007. Study of two-stage anaerobic digestion of solid potato waste using reactors under mesophilic and thermophilic conditions. Environmental Technology, 28: 1205-1216.

Parawira, W., Read, J. S., Mattiasson, B., and Björnsson, L. 2008. Energy production from agricultural residues: high methane yields in pilot scale two-stage anaerobic digestion. Biomass and Bioenergy, 32:44-50.

Pavlostathis, S.G. and Giraldo-Gomez, E. 1991 Kinetics of anaerobic treatment. Water Science Technology, 24, 35 - 59 . 
PISCES and FAO 2009. Small-scale bioenergy initiatives. http:/ / www.impattoambientale.it/documenti/Rapporto\%20FAO\%202009.pdf [accessed 10 October 2011].

Rajeshwari, K.V., Balakrishnan, M., Kansal, A., Kusum Lata, and Kishore, V.V.N. 2000 Stateof-the-art of anaerobic digestion technology for industrial wastewater treatment. Renewable and Sustainable Energy Reviews, 4, 135-156.

Rebac, S., van Lier, J.B., Janssen, M.G.J., Dekkers, F., Swinkels, K.T.M., and Lettinga, G.1997 High rate anaerobic treatment of malting waste water in a pilot-scale EGSB system under psychrophilic conditions. Journal of Chemical Technology and Biotechnology, 68, 135-146.

Rushbrook PE. Co-disposal of industrial wastes with municipal solid wastes. Resource Conservation Recycling 1990;4:33-49.

Sika, JM (2010). The Tanzania Domestic Biogas Programme gets up to speed! http://www.hivos.nl/english/News/News/The-Tanzania-Domestic-BiogasProgramme-gets-up-to-speed [accessed 10 October 2011].

Singh K.J., Sooth S.S. 2004. Comparative study of economics of different models of family size biogas plants for state of Punjab, India. Energy Convers Manage, 45:1329-41.

Smith, K.R., Rogers, J. \& Cowlin, S.C. 2005. Household fuels and ill-health in developing countries: what improvements can be brought by LP gas (LPG)? Paris, France, World LP Gas Association \& Intermediate Technology Development Group.

Switzenbaum, M.S. 1995. Obstacles in the implementation of anaerobic treatment technology. Bioresource Technology, 53, 255-262.

Tafdrup, S. 1995. Viable energy production and waste recycling from anaerobic digestion of manure and other biomass materials. Biomass and Bioenergy, 9, 303-314.

Tafdrup S. 1994. Centralised biogas plants combine agricultural and environmental benefits with energy production. Water Science and Technology,30:133-141.

Taleghani G, Kia AS. 2005. Technical-economical analysis of the Saveh biogas power plant. Renewable Energy. 30:441-6.

Tarlton JE (Undated). Woodfuel in Ciskei: a headload study. http://www.odi.org.uk/resources/libraries/forestry-grey-literature/headload.pdf [accessed 9 September 2011].

The Bioenergy Site ,2009. Tanzania sisal biogas. http://www.thebioenergysite.com/articles/308/tanzania-sisal-biogas [accessed 10 October 2011].

The East African 2011. Tanzania to double sisal-fired biogas capacity, 3 July. http:/ / allafrica.com/stories/201107041813.html [accessed 25 September 2011].

UNIDO 2008. Inauguration of the first sisal biogas electricity pilot plan in the world. http://www.unido.org/index.php\%3Fid\%3D4835\%26ucg_no64\%3D1/DATA1/D ATA1/Vacancy/fileadmin/user_media/PMO/IDB38/doc/index.php?id=7881\&tx _ttnews[tt_news] $=244 \& c H a s h=f 33 e 93 f 0 c 4 a 4$ efc60ed7f7ee5f149b47 [accessed 10 October 2011].

United Nations 2007. World urbanization prospects: the 2007 revision population database.

http://esa.un.org/unup/p2k0data.asp [accessed 11 October 2011]. 
United Nations 2010. Number of city dwellers grows amidst continuing disparities in level and pace of urbanization worldwide.

http:/ / esa.un.org/unpd/wup/Documents/WUP2009_Press-

Release_Final_Rev1.pdf [accessed 29 September 2011].

United Nations Convention to Combat Desertification 2004. A carrying pillar in the global combat against land degradation and food insecurity. Background paper for the San Rossore meeting 'Climate change: a new global vision' Pisa, Italy,15 - 16 July 2004.

United Nations Economic and Social Council 2007. Africa review report on drought and desertification.

http://www.un.org/esa/sustdev/csd/csd16/rim/eca_bg3.pdf [accessed 9 September 2011

van Lier, J.B., Van der Zee, F.P., Tan, N.C.G., Rebac, S. and Kleerebezem, R. 2001 Advances in high rate anaerobic treatment: staging of reactor systems. Water Science and Technology, 44, 15-25.

Viéitez, E.R. and Ghosh, S. 1999 Biogasification of solid wastes by two-phase anaerobic fermentation. Biomass and Bioenergy, 16, 299-309.

Weiland, P. 2000 Anaerobic waste digestion in Germany - Status and recent developments. Biodegradation, 11, 415-421.

World Bank, World development indicators, 2003, World Bank, Washington DC, 2003.

World Bank, 1980. Alcohol production from biomass in developing countries, Washington DC, USA.

World Economic Outlook 2010. Access to electricity. http://www.iea.org/weo/electricity.asp [accessed 30 September, 2011]

Zeeman, G. and Saunders, W. 2001. Potential of anaerobic digestion of complex waste (water)s. Water Science and Technology, 44, 115-122. 


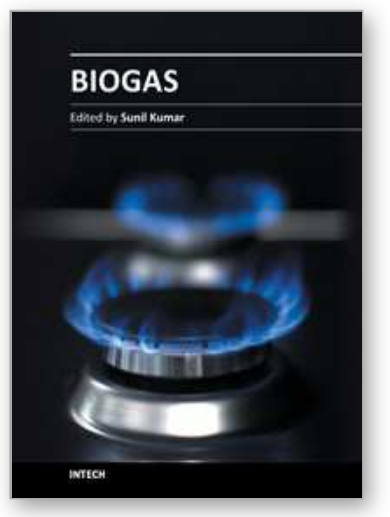

\section{Biogas}

Edited by Dr. Sunil Kumar

ISBN 978-953-51-0204-5

Hard cover, 408 pages

Publisher InTech

Published online 14, March, 2012

Published in print edition March, 2012

This book contains research on the chemistry of each step of biogas generation, along with engineering principles and practices, feasibility of biogas production in processing technologies, especially anaerobic digestion of waste and gas production system, its modeling, kinetics along with other associated aspects, utilization and purification of biogas, economy and energy issues, pipe design for biogas energy, microbiological aspects, phyto-fermentation, biogas plant constructions, assessment of ecological potential, biogas generation from sludge, rheological characterization, etc.

\section{How to reference}

In order to correctly reference this scholarly work, feel free to copy and paste the following:

B. Amigun, W. Parawira, J. K. Musango, A. O. Aboyade and A. S. Badmos (2012). Anaerobic Biogas Generation for Rural Area Energy Provision in Africa, Biogas, Dr. Sunil Kumar (Ed.), ISBN: 978-953-51-0204-5, InTech, Available from: http://www.intechopen.com/books/biogas/anaerobic-biogas-generation-for-rural-areaenergy-provision-in-africa

\section{INTECH}

open science | open minds

\section{InTech Europe}

University Campus STeP Ri

Slavka Krautzeka 83/A

51000 Rijeka, Croatia

Phone: +385 (51) 770447

Fax: +385 (51) 686166

www.intechopen.com

\section{InTech China}

Unit 405, Office Block, Hotel Equatorial Shanghai

No.65, Yan An Road (West), Shanghai, 200040, China

中国上海市延安西路65号上海国际贵都大饭店办公楼 405 单元

Phone: $+86-21-62489820$

Fax: +86-21-62489821 
(C) 2012 The Author(s). Licensee IntechOpen. This is an open access article distributed under the terms of the Creative Commons Attribution 3.0 License, which permits unrestricted use, distribution, and reproduction in any medium, provided the original work is properly cited. 